\title{
A Study of Compliment Responses Used by Indonesians
}

\author{
Intan Permata Hapsari ${ }^{1}$ \\ $\underline{\text { intan74@mail.unnes.ac.id }}^{1\}}$ \\ Universitas Negeri Semarang, Semarang, Indonesia ${ }^{1}$
}

\begin{abstract}
The Indonesian compliment responses were chosen to be explored since they had many functions. The problems to solve in this study are: (1) what speech functions are used to respond to Indonesian compliment, (2) how are those speech functions realized. The subjects of this study were Indonesian speakers. The main concern in this study was their verbal interaction (face-to-face) and emphasized the text containing the compliment and its response which constitute the limitation of this study. The study was based on the model of speech function network offered by Eggins \& Slade (1997). The explored speech functions performed by the compliment responses were analyzed using register analysis (field, mode, tenor). Compliments are all around us. Therefore the study of compliments and their responses is important because they reveal information about nation's culture, in this case is the Indonesian culture, and speech behaviour.
\end{abstract}

Keywords: compliment, speech function, field, mode, tenor

\section{Introduction}

A human being is a social creature who always interacts with one another in his daily life. Social interaction is the kind of harmonious relation among individuals, society group or social groups, and language is the means of communication used among the members of the community. Language and society are so intertwined that it is impossible to understand one without the other. All human societies are shaped by language, and language itself is shaped by society. Every social institution is maintained by language. Law, religion, government, education, the family, all are carried on with language. Almost all of our contact with others involves speaking.

People speak differently according to their background. Often, the social characteristic of one person can be determined from his speech, his place of origin, education, social group, and even occupation. Also, they speak differently according to how close they feel to their interlocuters, or according to the actual circumstances they find themselves at a particular time. The basically social nature of human language in communication is politeness. Politeness is basic to the production of social order, and a precondition of human cooperation. In addition to their status as universal principles of human interaction, politeness phenomena by their very nature are reflected in language. Societies everywhere, no matter what their degree of isolation or their socioeconomic complexity, show these same principles at work; yet what counts as polite may differ from group to group, from situation to situation, or from individual to individual.Therefore in human social life, politeness has to be communicated, and the absence of communicated politeness may be taken as absence of the polite attitude 
Politeness strategies can be a way of encoding distance between speakers and their addressees. Politeness phenomena is considered as a means of characterizing the use of language to communicate. Politeness Principles have been considered to have wide descriptive power in respect of language use (Lakoff, 1972; 1973), to be major determinants of linguistic behaviour (Leech, 1983), and to have universal status and linguistic manifestation (Brown and Levinson, 1978; 1987) [8]. Politeness Principle consists of a set of maxims in accordance with Grice's terminology; Tact Maxim, Generosity Maxim, Approbation Maxim, Modesty Maxim, Agreement Maxim, and Sympathy Maxim.

Complimenting and its response constitute the part of variety and complexity of communication acts and part of the Approbation Maxim and the Modesty Maxim which occur in our conversation. Compliment is also a speech act which is as a part of appraisal that refers to the attitudinal colouring of talk along a range of dimensions. Compliments as positive speech act are used to express friendship and increase rapport between people [16]. People usually tend to compliment or praise someone's ability, appearance, and possessions which draws his or her attention and amazes him or her. Compliment and its response are the example of the classic adjacency pairs. Conversational sequences where there was some kind of "special relatedness" operating between adjacent utterances are called adjacency pairs. Therefore, there is usually a response from the recipient when the complimenter compliments or praises him or her. The way of the recipient responding to compliment varies between one another. In responding the compliment, the recipient tends to answer it by using verbal feature \{acceptance (agreement) and rejection (disagreement and avoidance of self-praise) $\}$ or nonverbal feature \{gestures, eye contact, smiling, body language .

The researcher finds that Indonesian speakers have various types of responding to compliment, such as these following:

Aprilina: Ih, bajunya apik ik, mesti mahal nih. (Hey, your dress is good, it must be expensive)

Ninik : Ah, nggak juga tuh. (Oh no, not really)

Bu Nur : Kamu tuh badannya bagus lho, Ret. (Your body is good, Ret)

Retno : Enggak ah bu. (No, it's not)

Based on the Modesty Maxim, the recipients tend to go to minimize praise of self and maximize dispraise of self. Here, Ninik and Retno tend to avoid selfpraise and try to deny the truth of the compliments which are expressed by the complimenters.

It appears that in Indonesian society, the Modesty Maxim is more powerful than it is as a rule in English-speaking societies, where it would be customarily morepolite to accept a compliment graciously (e.g. by thanking the speaker for it) rather than to go on denying it. English-speakers would be inclined to find some compromise between violating the Modesty Maxim and violating the Agreement Maxim.

\subsection{Research Objective}

This research aims at analyzing further concerning how Indonesians respond to compliment. The problems of the study are: (1) what speech functions are used to respond to Indonesian compliment? and (2) how are those speech functions realized? 


\section{Research Methods}

\subsection{Research Type}

The study used an ethnographic methodology. Ethnograpic study examines questions to develop social science and educational theories, provide descriptive-analytical interpretations of educational phenomena, and assess the worth of a practice [26]. Therefore, ethnograpy is the appropriate methodology in this exploratory and discovery-oriented study. The researcher tried to give a picture of the Indonesian compliments and their responses. Then, she explored the speech functions performed by the compliment responses, the register variables of each text and the appraisals used in each text suggested by Eggins and Slade (1997).

\subsection{Research Subjects}

The subjects of this study were Indonesian speakers and also enabled for Javanese speakers to get involved as the writer lives in Semarang in which most of the people use both Javanese and Indonesian language.

\subsection{Data Collection Technique}

The main concern in this study was their verbal interaction (face-to-face). The researcher emphasized the text containing the compliment and its response which constitute the limitation of this study. The study took place in any place and at any time depend on where the researcher was at that time. she did not give any restrictions for this case in order to have natural conversation for her data. The more material she had at her command, the more she ought to be able to pick up items and saw their recurrence and got some idea of what they might be doing. Then, from the various topics she would take a note only the speech act containing the compliment and its response she captured.

Since the study is qualitative in nature, the researcher became the main instrument of obtaining the data. The ideal would be when the investigator can play a legitimate role within the setting [21]. The researcher did observation by becoming a participant observer and belonged to the members of the group being studied. Participation observation is a major means of collecting data in this study. It gives a firsthand account of the situation under study. Participation observation will maximize the advantage of human being as instrument.

\subsection{Data Analysis Technique}

During the observation, the researcher took a note in the form of data cards. Each card contains the description of the setting, the people and their activities, and direct quotation of what they said. Then she conducted this analysis in three stages. These stages were based on the model analysis she had chosen, the speech function network of conversation, the appraisal analysis [4] and the register analysis including field, mode and tenor [12].

1. The speech function analysis had these following steps:

a. The first step was identifying the turns and moves of each of the texts. The identification must also deal with non-verbal realizations of move. For example:

$$
\text { O:I:statement:opinion } \quad \text { Mei } \quad \text { Duh, keren banget }
$$

(Tsk, you're so handsome) 


\section{Rs:r:accept}

O:I:statement:opinion

Rs:non-verbal
Nugroho: Makasih (Thanks)

$$
\begin{array}{cl}
\text { Tyaa } & : \text { Wah 'stil' nih } \\
& \text { (Hey ! You look stylish) } \\
\text { Ninuk } \quad: \text { [tertawa] / [laughter] }
\end{array}
$$

b.The second step was assigning a speech function label, based on the most righthand categories in the network. Speech function coding can only be done contextually: that is, the function of each move can only be decided by looking at its relationship to prior moves. For example, we can only classify Nugroho's move above as an acceptance by relating it back to the Mei's move. In initial coding it is advisable to interpret the function of each move in relation to only one other move, i.e. the nearest relevant prior move [4]. This is straightforward with dialogue, where typically what each person says relates to the immediately prior turn by the other person.

2. The register analysis included the analysis of field (what the language is being used to talk about), mode (the role language is playing in the interaction), and tenor (the role relationships between the interactants).

\section{Result and Discussion}

Most compliments refer to just a few broad topics: appearance (e.g. face, clothes, hair), a good performance which is the result of skill or effort, possessions (especially new ones), and some aspect of personality or friendliness. In each compliment uttered by a complimenter there is usually a response from recipient. Here the researcher elaborates each of the Indonesian compliment response based the function of the response. Each function is completed with the

\begin{tabular}{|c|c|c|c|}
\hline No & $\begin{array}{l}\text { Speech } \\
\text { Function }\end{array}$ & Congruent Mood & Realization \\
\hline 1. & Accepting & $\begin{array}{l}\text { Non-verbal, } \\
\text { expressions of } \\
\text { thanking }\end{array}$ & $\begin{array}{l}\text { Terima kasih; Amin; Aduh, saya jadi tersanjung; } \\
\text { Insha Allah; Alhamdullillah. }\end{array}$ \\
\hline 2. & Agreeing & $\begin{array}{l}\text { Yes, positive } \\
\text { polarity }\end{array}$ & $\begin{array}{l}\text { Jelas dong; Siapa dulu dong tantenya; Alah Bu Mila } \\
\text { aja juga cantik kok; Udah dari dulu; Ah, Nila bisa } \\
\text { aja; Ah, Mas Har ni lho; } \\
\text { Nah itu, berhubung nggak punya modal } \\
\text { jadinya bukan peragawan, tapi warta wan; Ketawa } \\
\text { dong; Ah, jangan gitu, malu; } \\
\text { Emang; Orang aslinya juga cantik; } \\
\text { Hmm, dari deket juga cakep kok; Yo'i; Pak Dodi bisa } \\
\text { aja, baru tau ya; Iya nih, akan ngikutin saran Mbak } \\
\text { Ida, } \\
\text { biar rambut nggak kusut, lusuh dan rusak; Iya, ini } \\
\text { kan yang dibeliin bapak; } \\
\text { Kok heran sih, kan udah dari dulu; } \\
\text { Baru tau?; [keep singing]. }\end{array}$ \\
\hline 3. & Affirming & $\begin{array}{l}\text { Yes, positive } \\
\text { polarity }\end{array}$ & $\begin{array}{l}\text { Ya, iya lah bu masak cewek ganteng; Iyo je, ayu } \\
\text { tenan. }\end{array}$ \\
\hline
\end{tabular}
register description (field, mode, tenor). The Indonesian compliment response functions as:

Table 1. The Summary of Speech Functions Used 


\begin{tabular}{|c|c|c|c|}
\hline 4. & Disavowing & $\begin{array}{l}\text { Expressions of } \\
\text { disclaiming } \\
\text { knowledge }\end{array}$ & $\begin{array}{l}\text { Saya nggak merasa gitu tu, kayaknya biasa aja; } \\
\text { Lumayan; Ah, nggak juga tuh. }\end{array}$ \\
\hline 5. & $\begin{array}{l}\text { Contradictin } \\
\mathrm{g}\end{array}$ & $\begin{array}{l}\text { No; switched } \\
\text { polarity }\end{array}$ & $\begin{array}{l}\text { Seksi gimana, orang gembrot gini dibilang seksi; } \\
\text { Enggak ah bu. }\end{array}$ \\
\hline 6. & Confirming & $\begin{array}{l}\text { Elliptical wh- } \\
\text { interrogative; } \\
\text { wh element from } \\
\text { prior move }\end{array}$ & Oh ya?; O, ya? Beneran nih?; Tenane?; Ndak yo?. \\
\hline 7. & Probing & $\begin{array}{l}\text { Full clause, new } \\
\text { subject, etc. but in } \\
\text { logico-semantic } \\
\text { relation } \\
\text { with the moves it's } \\
\text { tracking } \\
\text { or tagged } \\
\text { declarative } \\
\end{array}$ & $\begin{array}{l}\text { Knapa? mau?; Bagus beneran nggak?; Pengen } \\
\text { nglamut?. }\end{array}$ \\
\hline 8. & Resolving & $\begin{array}{l}\text { Elliptical } \\
\text { declarative; mood } \\
\text { adjunct of polarity } \\
\text { or modality }\end{array}$ & $\begin{array}{l}\text { Lha ini lho baju yang aku beli kemaren di butik Plaza } \\
\text { Mandiri; Iya tak rawatin di Affandi. }\end{array}$ \\
\hline 9. & Detaching & $\begin{array}{l}\text { Silence; expression } \\
\text { of termination }\end{array}$ & Nggak mau ditanya. \\
\hline 10. & Rebounding & $\begin{array}{l}\text { Wh-interrogative, } \\
\text { elliptical }\end{array}$ & $\begin{array}{l}\text { Hayo ngapa? muji-muji pasti ada maunya nih; Alah } \\
\text { boong?. }\end{array}$ \\
\hline 11. & $\begin{array}{l}\text { Re- } \\
\text { challenging }\end{array}$ & $\begin{array}{l}\text { Elliptical } \\
\text { interrogative }\end{array}$ & Saingan po? \\
\hline 12. & Refuting & $\begin{array}{l}\text { Elliptical } \\
\text { declarative; } \\
\text { negation }\end{array}$ & Ngenyek. \\
\hline 13. & $\begin{array}{l}\text { [Laughter / } \\
\text { Smile] }\end{array}$ & Non-verbal & [laughter/smile] \\
\hline
\end{tabular}

\subsection{Interpretation of Speech Function Used}

After examining the eighty-five texts, the researcher finds that Indonesian compliments are responded in various ways by the recipients. Most of them (22 recipients) responded the compliment with a laughter or smile. This suggests that the recipients might not want to show their feeling of pride and happiness complimented by the complimenters. Each culture smiles in somewhat different ways for somewhat different purposes [2]. They actually accept the compliments. However, it may be influenced by Indonesian culture and value that a person must be modest and low profile. Modesty is something recommended.

The twenty-one recipients responded the compliment by accepting it directly (e.g. Terima kasih) or indirectly (Aduh, saya jadi tersanjung). This suggests that the recipients may be influenced by the western culture. Western people assume that it would be customarily more polite to accept a compliment graciously (e.g. by thanking the complimenter for it) rather than to go on denying it. Meanwhile, the twenty recipients agreed with the compliment given. It may show that they are sure the compliments given are appropriate with the reality although some of them respond the compliments indirectly (e.g. Alah Bu Mila aja juga cantik kok). 
In responding the compliment given, the recipients also used the various ways such as affirming (two recipients), disavowing (three recipients), contradicting (two recipients), confirming (five recipients), probing (three recipients), resolving (two recipients), detaching (one recipient), rebounding (two recipients), re-challenging (one recipient) and refuting (one recipient).

Compliments are used a little bit more frequently by women than by men, and that women are complimented more often than men. Women give and receive significantly more compliments than men do. Women in fact compliment each other compared with men. Compliments between males are much less frequent even taking account of females' compliments to males, men receive considerably fewer compliments than women.

Most compliments refer to someone's appearance (e.g. face, clothes, hair) and some refer to a good performance which was the result of skill or effort, possessions and aspect of personality. Women tend to receive most compliments on their appearance, and they compliment each other most often on aspects of their appearance.

\subsection{Interpretation Based on the Register Analysis}

In responding the compliment, Indonesian people respond it in various speech functions. It means that the complimenter and the recipient interact face-to-face. They typically use the language to achieve some on-going social actions i.e. to give opinion, to compliment or praise someone's appearance, possessions and ability which draws his or her attention and amazes him or her. In such situation, there is both aural and visual contact thus feedback is immediate.

The field of the texts is complimenting or giving praise to someone's appearance, possessions and ability which draws someone's attention and amazes him or her. The language used in the interaction actually is everyday language. It means that all the words are acceptable and understandable for layperson. The compliment and its response occur not only in formal setting but also in informal condition. There are twenty-nine out of eighty-five interactions that take place in formal setting.

The power relationships between the complimenters and the recipients mostly are equal (close friends, lovers, husband and wife, sisters, brother and sister, cousins). The tenor of the texts are informal. The interactants see each other frequently, and are affectively involved. Meanwhile, there are twenty-five out of eighty-five texts in which the complimenters and the recipients have unequal status (assistant director - lecturer, headmaster - staff, lecturer - staff, lecturer - student, landlady - roomer, employer - employee, senior student - junior student, host / hostess - guest stars, uncle / aunt - niece). Although the power relationships between the interactants are unequal, these do not mean that the contacts between the interactants are infrequent, and their affective involvements are low. These can be seen from the power relationships between uncle/aunt and his/her niece. The power relationship between them is unequal. However, their affective involvement is high since their contact is frequent.

\section{Conclusion}

Compliments are positive speech acts which are used to express friendship and increase rapport between people. When the complimenter compliments or praises someone, there is usually a response from the recipient. The response given by the recipient, Indonesian people, are various. The Indonesian compliment responses function as: accepting (to accept proffered 
goods and services), agreeing (to indicate support of information given), affirming (to provide positive response to question), disavowing (to deny acknowledgement of information), contradicting (to negate prior information), confirming (to verify information heard), probing (to volunteer further details / implications for confirmation), resolving (to provide clarification acquiesce with information), detaching (to terminate interaction), rebounding (to question relevance, legitimacy, veracity of prior move), re-challenging (to offer alternative position), refuting (to contradict import of a challenge), laughter/smile (non-verbal response which may have hidden meaning in which depends on the context)

In order to understand how the recipients choose the responses, it is necessary to consider both the context of situation and the context of culture. The former suggests that language only becomes intelligible when it is placed within its context of situation. The context of situation is described in terms of three variables: field, tenor and mode; whereas the latter suggests that in order to know the purpose of language use, it is necessary to relate the text to a cultural context.

After examining both, the researcher finds that the mode of the eighty-five texts are similar. The Indonesian compliments and their responses are used in spoken where the complimenters and the recipients interact face-to-face. Thus, the feedback is immediate.

The field of the eighty-five texts are complimenting or giving praise to someone's appearance, possessions and ability which draws someone's attention and amazes him or her. The fields are ranging from formal setting to the informal situation. The interpersonal relationships between the interactants (tenor) mostly are equal (close friends, lovers, husband and wife, sisters, brother and sister, cousins) uncle / aunt and niece). Meanwhile, the twentyfive out of eighty-five texts have unequal interpersonal relationships (assisstant director lecturer, headmaster - staff, lecturer - staff, lecturer - student, landlady - roomer, employer employee, senior student - junior student, host / hostess - guest stars, uncle / aunt - niece).

It has been reviewed, besides the context of situation (field, mode, tenor), the context of culture (genre) involves language use. Therefore, language is so crucial in explaining a genre. That genre is realized (encoded) through language, and that this process of realizing genre in language is mediated through the realization of register. Thus, the context of culture (complimenting genre) also affects the recipients in responding the compliment. 


\section{References}

[1] Brown, P. and Levinson, S.C.: Universals in Language Usage: Politeness Phenomena, in Goody (1978: 56-311), reprinted with new introduction and revised bibliography as. (1978).

[2] Chaika, E.: Language the Social Mirror. Massachusetts: Newbury House Publishers, Inc. (1982).

[3] Eggins, S.: An Introduction to Systemic Functional Linguistics. London: Pinter. (1994).

[4] Eggins, S. and D. Slade.:Analysing Casual Conversation. London: Cassell. (1997).

[5] Fairclough, N.: Language and Power. London: Longman. (1989).

[6] Fairclough, N.: Critical Discourse Analysis: The Critical Study of Language. London: Longman. (1995).

[7] Goody, E., ed.: Questions and Politeness: Strategies in Social Interaction. Cambridge. (1978).

[8] Grundy, P.: Doing Pragmatics. London: Edward Arnold. (1995).

[9] Gumperz, John J.: Discourse Strategies. Cambridge: Cambridge University Press. (1982).

[10] Halliday, M.A.K.: Learning How to Mean: Exploration in the Development of Language. London: Edward Arnold. (1975).

[11] Halliday, M.A.K.: Language as Social Semiotic. London: Edward Arnold. (1978).

[12] Halliday, M.A.K. and R. Hasan.: Language, Context, and Text: Aspects of Language in a Social-Semiotic Perspective. Victoria: Deakin University Press. (1985).

[13] Halliday, M.A.K.: An Introduction to Functional Grammar. London: Edward Arnold. (1994).

[14] Hammond et al.: English for Special Purposes: A Handbook for Teachers of Adult Literacy. Sydney: NCELTR. (1992).

[15] Holmes, J.: An Introduction to Sociolinguistics. London: Longman. (1992).

[16] Holmes, J. The Role of Compliments in Female-Male Interaction, in Sunderland, J. Exploring Gender: Questions and Implications for English Language Education. London: Prentice Hall. (1994).

[17] Hudson, R.A.: Sociolinguistics. Britain: Cambridge University Press. (1980).

[18] Iedema, R., Feez, S. and White, P.: Media Literacy: Phase I of the Write it Right Industry Research Project. Metropolitan East Disadvantaged Schools Program, Sydney. (1994), in Eggins, S. and D. Slade.: Analysing Casual Conversation. London: Cassell. (1997).

[19] Lakoff, R.: Language in Context, Language 48: 907-927. (1972). in Grundy, P.: Doing Pragmatics. London: Edward Arnold. (1995).

[20] N/A.: The Logic of Politeness: or Minding Your P's and Q's', Papers from the Ninth Regional Meeting of the CL. Chicago: CLS. (1973) in Grundy, P.: Doing Pragmatics. London: Edward Arnold. (1995).

[21]Lancy, D.F.: Qualitative Research in Education: An Introduction to the Major Traditions. New York: Longman. (1993).

[22]Leech, G.N.: Principles of Pragmatics. Harlow: Longman. (1983).

[23] Martin, J.R.: English text: System and Stucture. Amsterdam: Benjamins. (1992).

[24] Martin, J.R.: Course Notes for the Subject 'Writing', MA in Applied Linguistics Program, Linguistics Department, University of Sydney. (1994) in Eggins, S. and D. Slade.: Analysing Casual Conversation. London: Cassell. (1997).

[25] Matthiessen, C.: Lexicogrammatical Cartography: English Systems. Tokyo: International Language Sciences. (1995). 
[26] Mc Millan, James H. and Sally Schumacher.: Research in Education, A Conceptual Introduction (2nd ed). Illinois: Scott Foresman and Company. (1989).

[27] Poynton, C.: Language and Gender: Making the Difference. Geelong, Vic: Deakin University Press. (1985) in Eggins S.: An Introduction to Systemic Functional Linguistics. London: Pinter. (1994).

[28] Schiffrin, D.: Approaches to Discourse. Oxford: Blackwell. (1994).

[29] Silverman, D.: Interpreting Qualitative Data: Methods for Analysing Talk, Text and Interaction. London: SAGE Publications. (1993).

[30] Swales, J.M.: Genre Analysis: English in Academic and Research Settings. Cambridge: Cambridge University Press. (1990).

[31] Trudgill, P.: Sociolinguistics: An Introduction to Language and Society. England: Penguin Books. (1987).

[32] Wardhaugh, R.: An Introduction to Sociolinguistics. Oxford: Blackwell. (1986).

[33]Zhihui, Sun.: A Study of Gender Differences in Compliments and Compliment Responses in Chinese Context. Anhui University, China. (2002). 